University of Rhode Island

DigitalCommons@URI

The Rhode Island Current Conditions Index

Economics

2-2014

\title{
Rhode Island Current Conditions Index - February 2014
}

Leonard Lardaro

University of Rhode Island, lardaro@uri.edu

Follow this and additional works at: https://digitalcommons.uri.edu/ricci

Part of the Econometrics Commons

Terms of Use

All rights reserved under copyright.

\section{Recommended Citation}

Lardaro, Leonard, "Rhode Island Current Conditions Index -- February 2014" (2014). The Rhode Island Current Conditions Index. Paper 111.

https://digitalcommons.uri.edu/ricci/111

This Article is brought to you for free and open access by the Economics at DigitalCommons@URI. It has been accepted for inclusion in The Rhode Island Current Conditions Index by an authorized administrator of DigitalCommons@URI.For more information, please contact digitalcommons-group@uri.edu. 


\title{
CURRENT CONDITIONS
}

LEONARD LARDARO, URI

\author{
Available Online: http:/ / www .Ilardaro.com/ current.htm \\ Blog: http:/ / rieconomy.blogspot.com
}

VOL XXI

NUMBER 3

FEB 2014

The rugged winter weather that continued into February clearly took its toll on Rhode Island's overall economic performance, although there were still a number of areas where Rhode Island did well. The most obvious tragedy of the weather was new home construction, which was almost non existent in February. Yet at the same time, both Retail Sales and US Consumer Sentiment turned in very strong performances. The Current Conditions Index for February was 58, a decline from its (downwardly revised) value in J anuary of 67, and below the February 2013 value, which was also 67. However, I have scored the $\mathrm{CCl}$ for February with an asterisk - guilty with an explanation: were it not for the recorded plunge in Single-Unit Permits (to 26 units for the entire state), the value of the $\mathrm{CCl}$ would likely have been 67 , matching its values for last month and one year ago.

Yet even if that change had occurred, the $\mathrm{CCl}$ still would have failed to improve relative to its year-earlier value for a seventh consecutive month and eighth time in the last nine months. Clearly, these "misses" are not all, nor mostly, attributable to the weather over the past several months, so some slowing of our state's overall cyclical momentum is continuing. The upside to this, if there is one, is that payroll employment has been rising substantially more than we were led to believe with the data prior to the most recent rebenchmarking, and we just received word that December's employment number will be revised even higher. I guess this is Rhode Island's version of life in the fast lane!

For February, two of the $\mathrm{CCl}$ 's five leading indicators improved, while two failed to improve, and the fifth was highly weather distorted. Looking first at those that failed to improve,

\begin{tabular}{|l|r|}
\hline \multicolumn{2}{|c|}{ CCI Indicators - \% Change } \\
\hline Government Employment & 0.0 \\
\hline US Consumer Sentiment & $5.2 \mathrm{Y}$ \\
\hline Single-Unit Permits & -57.1 \\
\hline Retail Sales & $5.3 \mathrm{Y}$ \\
\hline Employment Services Jobs & -1.3 \\
\hline Priv. Serv-Prod Employment & $1.8 \mathrm{Y}$ \\
\hline Total Manufacturing Hours & $3.0 \mathrm{Y}$ \\
\hline Manufacturing Wage & $0.1 \mathrm{Y}$ \\
\hline Labor Force & -1.2 \\
\hline Benefit Exhaustions & $-23.7 \mathrm{Y}$ \\
\hline New Claims & 11.5 \\
\hline Unemployment Rate (change) & $-0.5 \mathrm{Y}$ \\
\hline \multicolumn{2}{|c|}{ Y = Improved Value } \\
\hline
\end{tabular}

Employment Service Jobs, which includes temporary employment and is a prerequisite to employment growth, fell by 1.3 percent in February, its third consecutive decline. However, based on the recent contradictory rebenchmarking changes to this indicator, the only thing I feel confident in concluding is that this indicator either increased, decreased, or remained unchanged in February. The other leading indicator that failed to improve, New Claims for Unemployment Insurance, is the timeliest measure of layoffs. For February, it rose by 11.5 percent compared to a year ago, its second failure to improve since last August. The downtrend in this indictor since July of 2013 may well have ended, which would be particularly bad news for our state. Finally, Single-Unit Permits, which was highly distorted by the weather, fell by 57.1 percent relative to a year ago. In spite of this, Rhode Island is continuing to move beyond its cyclical trough in new home construction.

US Consumer Sentiment rose by 5.2 percent in February, its third increase following three consecutive months of declines. The final leading indicator, Total Manufacturing Hours, which measures strength in our manufacturing sector, resumed strong growth in February $(+3.0 \%)$, boosted by increases in both the workweek and employment.

Retail Sales turned in a very strong performance in February, rising by 5.3 percent relative to a year ago. Keep in mind this indicator excludes clothing sales, which likely grew substantially in light of February's very cold weather. Private Service-Producing Employment, which was revised higher in the recent rebenchmarking, is displaying fairly strong growth. For February, it rose by 1.8 percent relative to last February. The performance of our state's Labor Force continued as it has for a while now - rates of decline continue to exceed one percent. February was its tenth consecutive decrease. Even with these declines, Rhode Island once again claimed the \#1 jobless slot in February, as our Unemployment Rate was $9 \%$. Let me confess that I am skeptical of these revised unemployment numbers in light of the improving performance of payroll employment. More on this next month. Finally, Government Employment was unchanged in February at just under 60,000.

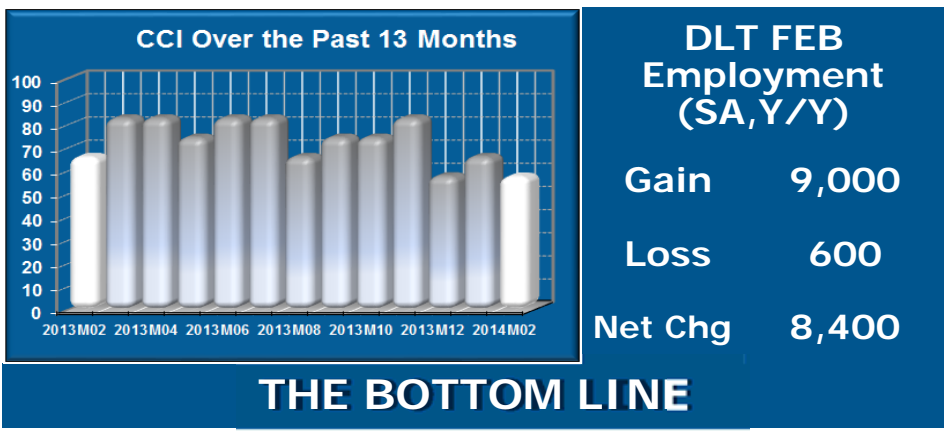

The present recovery continues to be less broadly based than it was a year ago, based on the fact that the $\mathrm{CCl}$ has now failed to exceed its year-earlier value for seven consecutive months. There are areas of strength, however, and payroll employment is growing faster than we had thought (although we remain $4.6 \%$ below our prior peak). A number of persons say we need to make drastic changes now, then propose ill-conceived solutions presupposing sales tax changes as "the solution." Rhode Island needs intelligent and well thought out investment-oriented solutions that are based on thorough due diligence. We need to stop "flying blind," that's what got us here!

\begin{tabular}{|l|l|l|l|l|l|l|l|l|l|l|l|l|l}
$*$ & Jan & Feb & Mar & Apr & May & J un & J ul & Aug & Sep & Oct & Nov & Dec \\
\cline { 2 - 13 } & 2013 & 75 & 67 & 83 & $83 \uparrow$ & $75 \downarrow$ & $83 \uparrow$ & 83 & 67 & $75 \uparrow$ & 75 & $83 \uparrow$ & $58 \downarrow$ \\
\cline { 2 - 13 } & 2014 & $67 \downarrow$ & $58 *$ & & & & & & & & & & \\
\hline
\end{tabular}

